\title{
Efek Penghambatan Ekstrak Akuades Daun Ocimum basilicum terhadap Streptococcus mutans In Vitro
}

\section{Inhibitory Effect of Aqueous Extract of Ocimum basilicum Leaves on Streptococcus mutans In Vitro}

\author{
Paulus Paksi IL', David Sugihartana ${ }^{1}$, Sri Larnani ${ }^{2}$ \\ ${ }^{1}$ Program Studi Pendidikan Dokter Gigi Fakultas Kedokteran Gigi Universitas Gadjah Mada Yogyakarta \\ ${ }^{2}$ Departemen Biomedika Kedokteran Gigi Fakultas Kedokteran Gigi, Universitas Gadjah Mada Yogyakarta
}

\begin{abstract}
ABSTRAK
Daun kemangi (Ocimum basilicum) telah diteliti ekstraknya sebagai antibakteri patogen pangan. Penelitian eksperimental antibakteri dari ekstrak daun Ocimum basilicum terhadap patogen di rongga mulut, termasuk Streptococcus mutans, masih harus diperdalam. Penelitian ini bertujuan untuk mengetahui efek ekstrak daun Ocimum basilicum terhadap penghambatan pertumbuhan Streptococcus mutans. Daun Ocimum basilicum diekstraksi dengan metode maserasi menggunakan akuades steril. Ekstrak diuji penghambatannya terhadap pertumbuhan Streptococcus mutans dalam larutan $\mathrm{NaCl}$ fisiologis dengan metode dilusi dan spektrofotometri 550nm. Hasil penelitian menunjukkan terdapat pengaruh yang signifikan perlakuan ekstrak daun Ocimum basilicum terhadap penghambatan pertumbuhan Streptococcus mutans $(p<0,05)$. Ekstrak daun kemangi (Ocimum basilicum L.) berpengaruh menghambat pertumbuhan Streptococcus mutans.
\end{abstract}

Kata Kunci: Ekstrak akuades, Ocimum basilicum, spektofotometri, Streptococcus mutans

\begin{abstract}
Basil (Ocimum basilicum) leaf extract has been studied as antibacterial food pathogens. An antibacterial experimental study of Ocimum basilicum leaf extract against pathogens in oral cavity, including Streptococcus mutans, still has to be explored. This study aimed to determine the effect of Ocimum basilicum leaf extract on the growth inhibition of Streptococcus mutans. Ocimum basilicum leaves were extracted by maceration method using sterile distilled water. The extract was tested for inhibition of the growth of Streptococcus mutans in physiological NaCl solution by dilution method and 550nm spectrophotometry. The results shows that there is a significant effect of Ocimum basilicum leaf extract on the growth inhibition of Streptococcus mutans ( $p$ <.05). Basil (Ocimum basilicum L.) leaf extract has an effect on inhibiting the growth of Streptococcus mutans.
\end{abstract}

Keywords: Aqueous extract, Ocimum basilicum, spectrophotometry, Streptococcus mutans

Korespondensi: Sri Larnani. Departemen Biomedika Kedokteran Gigi Fakultas Kedokteran Gigi, Universitas Gadjah Mada Yogyakarta. Sekip Utara Yogyakarta 55281 Tel. (0274) 515307 Email: Iarnani@ugm.ac.id

DOI: http://dx.doi.org/10.21776/ub.jkb.2018.030.02.2 


\section{PENDAHULUAN}

Tanaman yang termasuk dalam famili Labiatae telah digunakan secara tradisional oleh masyarakat Indonesia sebagai tanaman pangan dan penghasil bahan pewangi. Salah satu tanaman Labiatae yang digunakan oleh masyarakat luas adalah kemangi (Ocimum basilicum). Ocimum basilicum digunakan masyarakat untuk lalap dan pencegahan bau badan (1). Daun Ocimum basilicum secara tradisional berkhasiat sebagai obat untuk penyembuhan diare, disentri, konstipasi, dan penyakit cacingan (2).

Berbagai penelitian modern mengenai daun Ocimum basilicum yang dirangkum dalam sebuah review menunjukkan bahwa daun Ocimum basilicum memiliki aktivitas farmakologis, termasuk antibakteri (3). Hasil penelitian Ahonkhai et al., menunjukkan bahwa minyak atsiri daun Ocimum basilicum yang dibuat dalam bentuk sediaan murni, pasta gigi, dan obat kumur dapat menghambat bakteri Klebsiella pneumonia, Staphylococcus albus, Pseudomonas aeruginosa, Proteus vulgaris, dan Streptococcus viridans. Streptococcus viridans ditemukan dalam lesi gingivitis, periodontitis, dan karies gigi (4).

Streptococcus mutans termasuk dalam kelompok bakteri Streptococcus viridans yang dapat menyebabkan karies gigi karena menghasilkan asam dari fermentasi karbohidrat yang merusak mineral gigi $(5,6)$. Hasil penelitian antibakteri ekstrak akuades dari daun Ocimum basilicum dapat menghambat pertumbuhan bakteri patogen pangan, yaitu Pseudomonas sp., Enterobacter $s p .$, dan Listeria monocytogenes. Komponen terbesar daun kemangi adalah komponen polar yang larut air (7). Pengaruh ekstrak akuades daun Ocimum basilicum terhadap bakteri patogen mulut, termasuk Streptococcus mutans, masih belum diketahui. Penelitian ini bertujuan untuk mengetahui efek penghambatan ekstrak daun Ocimum basilicum terhadap pertumbuhan Streptococcus mutans.

\section{METODE}

\section{Ekstraksi Daun Ocimum basilicum}

Daun Ocimum basilicum didapatkan dari daerah Sleman, Yogyakarta. Ekstrak daun Ocimum basilicum dibuat di Laboratorium Biologi Farmasi Fakultas Farmasi Universitas Gadjah Mada Yogyakarta. Metode ekstraksi yang digunakan adalah maserasi dengan pengekstraksi akuades steril dan shaker 80 putaran per menit selama 24 jam. Hasil ekstraksi tersebut adalah ekstrak kental daun Ocimum basilicum. Ekstrak kental tersebut kemudian diencerkan dengan pelarut akuades steril menjadi konsentrasi $0,9375 \%, 1,875 \%, 3,75 \%, 7,5 \%$ dan $15 \%$. Konsentrasi tersebut dipilih berdasarkan konsentrasi ekstrak daun Ocimum basilicum dengan pelarut akuades yang dapat menghambat Listeria monocytogenes (7).

\section{Pembuatan Suspensi Streptococcus mutans}

Konsentrasi suspensi bakteri Streptococcus mutans yang digunakan dalam penelitian ini $10^{8}$ colony-forming unit $/ \mathrm{ml}$ dalam $\mathrm{NaCl}$ fisiologis dan dibuat dari stok di Balai Laboratorium Kesehatan Yogyakarta. Bakteri tersebut dibiakkan pada medium plat agar darah lalu diinkubasi selama 24 jam pada suhu $37^{\circ} \mathrm{C}$. Satu ose koloni bakteri diambil dari medium tersebut kemudian dimasukkan dalam tabung reaksi berisi $\mathrm{NaCl}$ fisiologis.

\section{Uji Penghambatan Pertumbuhan Streptococcus mutans}

Uji penghambatan pertumbuhan Streptococcus mutans dengan metode dilusi dan spektrofotometri $550 \mathrm{~nm}$ dilakukan di Laboratorium Mikrobiologi dan Laboratorium Riset Terpadu Fakultas Kedokteran Gigi UGM. Kaldu Brain Heart Infusion (BHI) steril sebanyak $3 \mathrm{ml}$ dimasukkan dalam enam tabung reaksi. Keenam tabung reaksi tersebut masing-masing kemudian diisi $1 \mathrm{ml}$ dari enam larutan yang berbeda, yaitu ekstrak daun Ocimum basilicum $0 \%$ (sebagai kontrol) dan ekstrak daun Ocimum basilicum konsentrasi $0,9375 \%, 1,875 \%, 3,75 \%, 7,5 \%$, dan $15 \%$ sesuai metode dilusi (8). Seluruh tabung larutan tersebut selanjutnya diberi suspensi Streptococcus mutans sebanyak $1 \mathrm{ml}$. Setiap larutan tersebut dibuat triplikasi.

Sebanyak $1 \mathrm{ml}$ dari setiap tabung reaksi dimasukkan ke dalam kuvet untuk diukur densitas optiknya sebelum diinkubasi (OD1) menggunakan spektrofotometer 550nm. Suspensi bakteri dapat diukur dengan densitas optik menggunakan spektrofotometer pada panjang gelombang $550 \mathrm{~nm}$ (9). Semua tabung reaksi tersebut kemudian diinkubasi selama 24 jam pada suhu $37^{\circ} \mathrm{C}$. Pengukuran densitas optik dilakukan lagi setelah inkubasi (OD2). Dari nilai OD1 dan OD2 tersebut, didapatkan nilai densitas optik final (ODf). Nilai ODf dihitung menggunakan persamaan $\mathrm{ODf}=\mathrm{OD2}-\mathrm{OD1}$. Nilai ODf sebagai hasil pengurangan dari pembacaan spektrofotometri sebelum dan sesudah inkubasi dibandingkan pada berbagai kelompok perlakuan, yaitu ekstrak daun Ocimum basilicum konsentrasi $0 \%, 0,9375 \%, 1,875 \%, 3,75 \%, 7,5 \%$, dan $15 \%$. Nilai ODf menyatakan pertambahan intensitas kekeruhan larutan dalam waktu 24 jam. Pertambahan intensitas kekeruhan larutan tersebut menunjukkan pertambahan koloni bakteri Streptococcus mutans yang tumbuh dalam jangka waktu 24 jam. Semakin tinggi pertambahan intensitas kekeruhan yang dihasilkan maka semakin banyak koloni Streptococcus mutans yang tumbuh. Begitu pula sebaliknya, semakin rendah pertambahan intensitas kekeruhan yang terbaca, semakin sedikit koloni Streptococcus mutans yang dapat tumbuh selama 24 jam.

\section{Analisis Statistik}

Data nilai ODf dinyatakan dalam bentuk rerata dan simpangan baku $(\bar{x} \pm S B)$. Data tersebut kemudian dianalisis secara statistik menggunakan IBM SPSS versi 18. Sebaran nilai ODf diuji normalitasnya dengan metode Shapiro-Wilk, sedangkan homogenitas variansinya diuji dengan metode Levene. Kedua metode tersebut diuji dengan taraf kepercayaan 95\%. Apabila sebaran nilai ODf normal dan variansinya homogen $(p>0,05)$, uji One Way ANOVA digunakan dengan taraf kepercayaan 95\%. Pengaruh signifikan kelompok ekstrak daun Ocimum basilicum terbukti dengan One Way ANOVA apabila $p<0,05$. Selanjutnya, perbedaan signifikan rerata antar kelompok perlakuan ekstrak daun Ocimum basilicum dianalisis dengan uji Least Significant Difference (LSD) dengan taraf kepercayaan $95 \%$.

\section{HASIL}

Hasil uji penghambatan pertumbuhan Streptococcus mutans berupa nilai ODf yang dinyatakan secara kuantitatif dalam angka desimal dari 3 kali replikasi pada kelompok perlakuan kontrol (ekstrak daun Ocimum basilicum 0\%) dan ekstrak daun Ocimum basilicum konsentrasi 0,9375\%, $1,875 \%, 3,75 \%, 7,5 \%$, dan $15 \%$. Nilai ODf dari ketiga replikasi tersebut kemudian dihitung rerata dan 
simpangan bakunya. Data rerata dan simpangan baku nilai ODf ditunjukkan dalam Gambar 1.

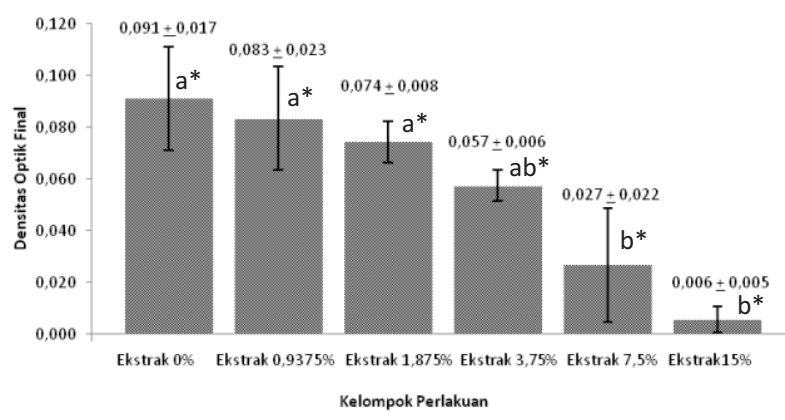

\section{Gambar 1. Rerata dan simpangan baku nilai ODf} Streptococcus mutans

Keterangan: *ab notasi berbeda menunjukkan perbedaan signifikan

Gambar 1 menunjukkan bahwa nilai ODf tertinggi pada ekstrak daun Ocimum basilicum $0 \%$ dan nilai ODf terendah pada ekstrak daun Ocimum basilicum konsentrasi $15 \%$. Nilai ODf semakin mengecil seiring semakin besarnya konsentrasi ekstrak daun Ocimum basilicum. Hasil analisis Shapiro-Wilk menunjukkan bahwa sebaran nilai ODf normal ( $p=0,433$ untuk ekstrak $0 \%, p=0,485$ untuk ekstrak $0,9375 \%, p=0,726$ untuk ekstrak 1,875\%, $p=0,298$ untuk ekstrak 3,75\%, p=0,605 untuk ekstrak 7,5\%, p=0,510 untuk ekstrak 15\%). Hasil uji Levene menunjukkan bahwa variansi data homogen $(p=0,088)$. Data nilai ODf kemudian dianalisis menggunakan uji One Way ANOVA. Hasilnya diketahui terdapat perbedaan signifikan $(p=0,000)$ dari nilai ODf antarkelompok perlakuan. Uji LSD menunjukkan bahwa perbedaan signifikan $(p<0,05)$ ditemukan antara kelompok ekstrak daun Ocimum basilicum 0\% dengan kelompok ekstrak daun Ocimum basilicum 3,75\%, 7,5\%, dan 15\%, antara kelompok ekstrak konsentrasi $0,9375 \%$ dengan konsentrasi $7,5 \%$ dan $15 \%$, serta antara kelompok ekstrak konsentrasi 1,875\% dengan konsentrasi $7,5 \%$ dan $15 \%$. Tidak ada perbedaan yang signifikan $(p>0,05)$ antara kelompok ekstrak daun Ocimum basilicum 0\% dengan kelompok ekstrak konsentrasi $0,9375 \%$ dan 1,875\%, antara kelompok ekstrak konsentrasi 0,9375\% dengan konsentrasi 1,875\% dan 3,75\%, antara kelompok ekstrak konsentrasi 1,875\% dengan konsentrasi 3,75\%, serta antarkelompok ekstrak daun Ocimum basilicum 3,75\%, 7,5\%, dan $15 \%$.

\section{DISKUSI}

Pengukuran turbiditas merupakan salah satu cara untuk mengukur pertumbuhan bakteri. Metode tersebut berdasarkan prinsip seiring bertambahnya bakteri dalam medium cair, medium tersebut semakin keruh. Intensitas kekeruhan medium diukur dengan spektrofotometer. Dalam spektrofotometer, berkas sinar dipancarkan melalui suspensi bakteri dalam medium untuk ditangkap oleh pendeteksi. Jika jumlah bakteri meningkat, sinar yang ditangkap pendeteksi menurun. Besarnya sinar yang ditangkap pendeteksi ini tercatat dalam spektrofotometer sebagai persentase transmisi. Nilai logaritma dari persentase transmisi tersebut ditampilkan oleh spektrofotomer dalam bentuk angka desimal. Nilai angka inilah yang disebut densitas optik (dalam bahasa Inggris optical density atau disingkat OD). Nilai OD tersebut digunakan untuk memantau pertambahan jumlah bakteri dalam rentang waktu tertentu (10).

Nilai OD dalam penelitian ini diukur dua kali, yaitu sebelum (OD1) dan sesudah inkubasi (Od2), untuk mengetahui ODf yang menunjukkan pertambahan bakteri. Rerata nilai ODf pada kelompok perlakuan ekstrak daun Ocimum basilicum 0\% (kontrol), ekstrak daun Ocimum basilicum 0,9375\%, $1,875 \%, 3,75 \%, 7,5 \%$, dan $15 \%$ bernilai positif (nilai ODf $>0$ ). Hal ini menunjukkan bahwa terdapat pertambahan jumlah bakteri Streptococcus mutans selama proses inkubasi 24 jam pada semua kelompok perlakuan. Pertambahan jumlah Streptococcus mutans tidak sama antara satu kelompok perlakuan dengan kelompok perlakuan yang lain. Nilai ODf tertinggi terdapat pada kelompok ekstrak $0 \%$, yaitu 0,091+0,017, yang menunjukkan bahwa lebih banyak Streptococcus mutans yang bertambah dalam 24 jam dibandingkan kelompok perlakuan lainnya. Sementara nilai terendah ODf pada kelompok perlakuan ekstrak daun Ocimum basilicum konsentrasi 15\%, yaitu sebesar $0,006 \pm 0,005$. Rerata ini menunjukkan bahwa pertambahan bakteri Streptococcus mutans paling sedikit pada ekstrak akuades daun Ocimum basilicum konsentrasi 15\%.

Hasil menunjukkan bahwa pemberian ekstrak daun Ocimum basilicum menunjukkan efek kadar ODf yang lebih rendah pada dosis 3,75\%, 7,5\%, dan 15\%. Nilai ODf menunjukkan pertambahan jumlah bakteri Streptococcus mutans dalam 24 jam. Perbedaan signifikan pertambahan jumlah bakteri dibandingkan dengan kontrol diduga karena adanya kandungan zat aktif dalam ekstrak akuades daun Ocimum basilicum pada konsentrasi 3,75\%, 7,5\%, dan $15 \%$. Hasil ini menunjukkan bahwa ekstrak akuades daun Ocimum basilicum memiliki daya antibakteri sehingga dapat menghambat pertumbuhan bakteri Streptococcus mutans. Hal ini sejalan dengan penelitian Parhusip et al. yang menyatakan bahwa ekstrak akuades daun Ocimum basilicum memiliki aktivitas antibakteri terhadap bakteri Listeria monocytogenes (7). Hasil penelitian ini juga mendukung penelitian Mishra dan Mishra mengenai kemampuan antibakteri dari ekstrak akuades daun Ocimum terhadap bakteri Staphylococcus aureus (11). Bakteri Listeria monocytogenes, Staphylococcus aureus, dan Streptococcus mutans samasama termasuk bakteri Gram positif dan anaerob fakultatif (10).

Hasil penelitian Kaya et al., menunjukkan bahwa kandungan dalam ekstrak daun Ocimum basilicum memiliki sifat antibakteri terhadap bakteri patogenik, yaitu Pseudomonas aeruginosa, Shigella sp., Listeria monocytogenes, Staphylococcus aureus, dan Escherichia coli (12). Bilal et al., dalam pembahasan review mengenai studi fitokimiawi dan farmakologis Ocimum basilicum menyatakan bahwa senyawa utama dari kandungan fitokimia ekstrak daun Ocimum basilicum yang paling bertanggung jawab terhadap setiap aktivitas farmakologis, termasuk daya antibakteri masih belum jelas (3). Hasan et al., dalam penelitiannya mengenai pengaruh ekstrak buah Emblica officinalis terhadap sifat kariogenik bakteri Streptococcus mutans menunjukkan bahwa terdapat pengaruh dari kerja sinergis berbagai senyawa dalam ekstrak tersebut terhadap penurunan sifat kariogenik Streptococcus mutans, termasuk penghambatan pertumbuhan bakteri tersebut (13). Dalam penelitian ini, kandungan fitokimiawi yang terkandung dalam ekstrak daun Ocimum basilicum tersebut diduga bekerja secara 
sinergis dalam menghambat pertumbuhan bakteri Streptococcus mutans.

Hasil penelitian Edriss et al., menunjukkan bahwa kandungan fitokimia ekstrak akuades daun Ocimum basilicum adalah flavonoid, saponin, dan alkaloid (14). Flavonoid diketahui menghambat pertumbuhan Streptococcus mutans (15). Dengan aktivitas antioksidasinya, flavonoid merusak dinding sel bakteri (16). Selain itu, flavonoid menghambat pembentukan dinding sel, merusak dan menghambat pembentukan membran sel, serta menghambat pembentukan asam nukleat bakteri $(17,18)$. Saponin merupakan senyawa mirip sabun yang bersifat antiseptik dan memiliki efek antibakteri (19). Saponin menurunkan tegangan permukaan membran sel bakteri dengan bekerja pada gugus fosfat fosfolipid dari membran sel. Saponin tersebut masuk ke dalam sel dan mendenaturasi protein sel sehingga sel bakteri membengkak dan pecah (20). Alkaloid menghambat pertumbuhan bakteri dengan mengganggu proses pembelahan sel bakteri (21). Alkaloid juga merusak dinding dan membran sel serta menghambat pembentukan protein dan DNA bakteri (22).

Hasil lain dari penelitian ini menunjukkan bahwa tidak terdapat perbedaan signifikan rerata nilai ODf Streptococcus mutans antara kelompok ekstrak daun Ocimum basilicum 0\% (kontrol) dengan kelompok ekstrak daun Ocimum basilicum konsentrasi 0,9375\% dan 1,875\%. Tidak ada perbedaan signifikan juga antara kelompok ekstrak konsentrasi $0,9375 \%$ dan $1,875 \%$ dengan konsentrasi 3,75\%, serta antarkelompok ekstrak daun Ocimum basilicum konsentrasi 3,75\%, 7,5\%, dan 15\%. Hal ini membuktikan bahwa ekstrak akuades daun Ocimum basilicum konsentrasi mulai $7,5 \%$ memiliki daya

\section{DAFTAR PUSTAKA}

1. Sirait N. Penggunaan Berbagai Jenis Tanaman Obat untuk Menanggulangi Bau Badan. Warta Penelitian dan Pengembangan Tanaman Industri. 2008; 14(3): 8-11.

2. Pushpangadan P and George V. Basil. In: Peter KV (Ed.). Handbook of Herbs and Spices. Volume 1. Second Edition. Cambridge: Woodhead Publishing; 2012; p. 55-72.

3. Bilal A, Jahan N, Ahmed A, Bilal SN, Habib S, and Hajra S. Phytochemical and Pharmacological Studies on Ocimum Basilicum Linn-A Review. International Journal of Current Research and Review. 2012; 4 (23): 73-83.

4. Ahonkhai I, Ba A, Edogun O, and Mu U. Antimicrobial Activities of the Volatile Oils of Ocimum Basilicum L. and Ocimum Gratissimum L. (Lamiaceae) against Some Aerobic Dental Isolates. Pakistan Journal of Pharmaceutical Sciences. 2009; 22(4): 405-409.

5. Dhotre S, Suryawanshi N, Selkar S, and Nagoba B. Viridans Group Streptococci and the Oral Ecosystem. European Journal of General Medicine. 2015; 13(2): 145-148.

6. Fatmawati DWA. Hubungan Biofilm Streptococcus Mutans terhadap Risiko Terjadinya Karies Gigi. Stomatognatic. 2011; 8(3): 127-130.

7. Parhusip AJN, Wijaya JR, dan Stenlie J. Aktivitas antibakteri terhadap Streptococcus mutans. Hal ini berbeda dengan hasil penelitian Parhusip et al., yang menyatakan bahwa ekstrak yang sama pada konsentrasi $15 \%$ menghambat bakteri Listeria monocytogenes (7). Hal ini mungkin disebabkan perbedaan genus dan spesies bakteri dan perbedaan metode uji penghambatan pertumbuhan bakteri yang digunakan.

Ekstrak akuades daun Ocimum basilicum mulai konsentrasi $7,5 \%$ berpengaruh menghambat pertumbuhan bakteri Streptococcus mutans. Ekstrak tersebut diperkirakan dapat menghambat pertumbuhan bakteri melalui perusakan dinding sel bakteri yang mempengaruhi metabolisme sel bakteri. Penelitian ini membutuhkan penelitian pendukung yang dapat meneliti persentase komponen antibakteri kandungan ekstrak akuades daun Ocimum basilicum, isolasi komponen tersebut, dan mekanisme kerja seluler dari komponen tersebut terhadap sel bakteri Streptococcus mutans.

Hasil penelitian membuktikan bahwa ekstrak akuades daun Ocimum basilicum pada konsentrasi 7,5\% dan 15\% memiliki efek penghambatan terhadap bakteri Streptococcus mutans, yaitu dengan menekan pertumbuhan jumlah bakteri dalam rentang waktu 24 jam. $\mathrm{Hal}$ ini menunjukkan potensi daun Ocimum basilicum sebagai bahan herbal dari alam Indonesia yang dapat diolah, diteliti dan dimanfaatkan dalam bidang kesehatan, termasuk kesehatan gigi dan mulut.

\section{UCAPAN TERIMA KASIH}

Ucapan terima kasih disampaikan kepada Universitas Gadjah Mada Yogyakarta. Penelitian ini mendapatkan dana dari Hibah Penelitian Kolaborasi Dosen-Mahasiswa UGM.
Antimikroba Ekstrak Daun Kemangi (Ocimum Basilicum L.) terhadap Mikroba Patogen Pangan. Jurnal Ilmu dan Teknologi Pangan. 2009; 7(2): 77-92.

8. Santosaningsih D, Zuhriyah L, and Nurani M. Staphylococcus Aureus pada Komunitas Lebih Resisten terhadap Ampisilin dibandingkan Isolat Rumah Sakit. Jurnal Kedokteran Brawijaya. 2011; 26(4): 204-207.

9. Sutton S. Measurement of Microbial Cells by Optical Density. Journal of Validation Technology. 2011; 17(1): 46-49.

10. Tortora GJ, Funke BR, and Case CL. Microbiology: An Introduction. 10th edition. San Francisco: Pearson Benjamin Cummings; 2010; p. 179, 301, 318.

11. Mishra P and Mishra S. Study of Antibacterial Activity of Ocimum Sanctum Extract against Gram Positive and Gram Negative Bacteria. American Journal of Food Technology. 2011; 6(4): 336-341.

12. Kaya I, Yiğit N, and Benli M. Antimicrobial Activity of Various Extracts of Ocimum Basilicum L. and Observation of the Inhibition Effect on Bacterial Cells by Use of Scanning Electron Microscopy. African Journal of Traditional, Complementary, and Alternative Medicines. 2008; 5(4): 363-369.

13. Hasan S, Danishuddin M, Adil M, Singh K, Verma PK, and Khan AU. Efficacy of Emblica officinalis on the Cariogenic Properties of Streptococcus Mutans: A 
Novel and Alternative Approach to Suppress Quorum-Sensing Mechanism. PLoS ONE. 2012; 7(7): 1-12.

14. Edriss AE, Alabjar ZA, and Satti AA. Phytochemical Screening of Important Secondary Metabolites in Some Extracts of Two Sudanese Plants. Global Advanced Research Journal of Environmental Science and Toxicology. 2012; 1(8): 199-202.

15. Ferrazzano GF, Amato I, Ingenito A, Zarrelli A, Pinto G, and Pollio A. Plant Polyphenols and Their AntiCariogenic Properties: A Review. Molecules. 2011; 16(2): 1486-1507.

16. Yahya NZ. In Vitro and in Vivo Evaluation of Antimicrobial Effect of Leaves Ocimum Basilicum of Ethanolic Extract against Staphylococcus Aureus. AlAnbar Journal of Veterinary Sciences. 2011; 4(2): 6775.

17. Cushnie TPT and Lamb AJ. Recent Advances in Understanding the Antibacterial Properties of Flavonoids. International Journal of Antimicrobial Agents. 2011; 38(2): 99-107.
18. Fitrianti D, Noorhamdani AS, dan Karyono SS. Efektivitas Ekstrak Daun Ceplukan sebagai Antimikroba terhadap Methicillin-Resistant Staphylococcus Aureus in Vitro. Jurnal Kedokteran Brawijaya. 2011; 26(4): 212-215.

19. Fani M and Kohanteb J. Inhibitory Activity of Aloe Vera Gel on Some Clinically Isolated Cariogenic and Periodontopathic Bacteria. Journal of Oral Science. 2012; 54(1): 15-21.

20. Berniyanti T and Mahmiyah E. Microbiological Studies on the Production of Antimicrobial Agent by Saponin Aloe Vera Linn against Streptococcus Sanguinis. Research Journal of Microbiology. 2015; 10(8): 486-493.

21. Singh V, Kuldeep, Bajaj A, and Kalra M. Green Tea: Enhancing Oral Health. University Journal of Dental Sciences. 2016; 2(1): 61-63.

22. Peng L, Kang S, Yin K, et al. Antibacterial Activity and Mechanism of Berberine against Streptococcus Agalactiae. International Journal of Clinical and Experimental Pathology. 2015; 8(5): 5217-5223. 